CS A. Grønn \& A. Pazelskaya (eds.) The Russian Verb, Oslo Studies in Language 4(1), 2012. 71-95. (ISSN 1890-9639)

http://www.journals.uio.no/osla

\title{
ОТ ГЛАГОЛА К СЛУЖЕБНОМУ СЛОВУ. ПУТИ ГРАММАТИКАЛИЗАЦИИ.
}

\author{
СОФИЯ ПОЖАРИЦКАЯ \\ Московский государственный университет
}

\section{[1] ВВЕДЕНИЕ}

Предметом исследования послужили диалектные (севернорусские) «мелкие слова», производные от форм глаголов быть, бывать (бы, бывает, будет), которые мы рассматриваем в составе синтаксических конструкций в связи с категорией модальности.

Материал был получен нами в процессе экспедиционного обследования говоров Архангельской области (Верхнетоемский, Вилегодский, Каргопольский, Ленский, Лешуконский, Мезенский, Онежский, Пинежский, Плесецкий, Устьянский р-ны) в связи с работой над Архангельским областным словарем (далее AOC).

Способом получения нужных нам сведений были непринужденные беседы с информантами и запись спонтанной речи диалектоносителей, в основном, диалогического характера. Метод прямых ответов на поставленные диалектологом вопросы не применялся. Были использованы также цитаты из опубликованных выпусков АОС и его электронной базы ${ }^{1}$. Благодаря этому нам удалось, хотя и весьма приблизительно, выявить ареалы наиболее интенсивного употребления каждого модального слова (союза или частицы) в пределах территории Архангельской обл. При этом выяснилось, что имеются зоны наложения ареалов разных модальных слов/частиц, производных от быть, бывать, и их дистрибуция в пределах частной диалектной системы представляет особый интерес, поскольку дает возможность более точно определить их семантику и связь с грамматическими структурами предложения. Приведенный в статье цитатный материал представляет собой выборку примеров, наиболее ярко иллюстрирующих разные типы синтаксических конструкций с бы, бывает, будет (буде) в связи с их семантикой. Полный объем материала мог бы быть обозрим после того, как завершится работа по записи его для словаря, которая в настоящее время еще продолжается. Следует отметить, что количество материала для отдельных регионов Архангельской обл. существенно зависит от заселенности

[1] Список населенных пунктов, в которых был записан цитатный материал (как обследованных нами, так и упомянутых в АОС), приводится нами в конце статьи. Фонетические особенности диалектов передаются в той мере, в какой они не требуют применения специальных средств транскрипции. 
соответствующей территории (и, следовательно, степени ее привлекательности для диалектологов), которая очень неравномерна: так, например, для Пинежского и Верхнетоемского районов количество имеющихся в нашем распоряжении цитат исчисляется сотнями, для Плесецкого и Онежского - десятками, для Ленского - единицами.

Материал других единиц диалектного членения русского языка не был использован для сопоставления, и перспектива его привлечения представляется весьма сомнительной в связи с тем, что мы не располагаем записями спонтанной речи с других территорий в достаточном объеме, поскольку остальная территория изучалась в основном лингвогеографическими методами, которые абсолютно непригодны для наших целей. Есть только все основания предполагать, что описываемые нами конструкции не замыкаются административными границами Архангельской обл., а распространяются за ее пределы на территорию северозападных и вологодских говоров; тем самым, западная и южная границы рассматриваемых явлений остаются пока неизвестными.

Единственным источником сведений, которые могли бы быть сопоставлены с нашими, мог бы послужить словарь рязанского говора (ССРНГ) с его богатым цитатным материалом и фонографическими записями, но в нем интересующие нас конструкции отсутствуют - очевидно, не случайно.

Формам глаголов быть, бывать принадлежит, несомненно, особая роль в образовании служебных слов в русском языке. Помимо употребления в своем экзистенциальном значении, эти глаголы участвовали в качестве вспомогательных элементов в образовании старых сложных форм времени: перфекта, плюсквамперфекта, футурума I и футурума II. Занимая позицию, способствующую клитизации, эти формы утрачивали как формальную, так и функциональную связь с глаголом и развивали новые синтаксические функции и значения, прежде всего - в качестве модальных слов/частиц.

В литературном русском такими «реликтами» глаголов быmb, бывать являются служебные слова бы, бывает, буде, бишь ${ }^{2}$, имеющие разный грамматичекий статус: бы - элемента формы сослагательного наклонения; бывает - частицы, «характеризующей действие по его протеканию во времени, по полноте или неполноте его осуществления, по результативности или нерезультативности» (АГ 1980, т. 1: 727), буде - условного союза, синонимичного если.

В севернорусских говорах эти слова обладают теми же грамматическими функциями, что и в литературном языке, но наряду с этим диалектная (севернорусская) речь демонстрирует некоторые иные, по сравнению с литературным

[2] Имеется другая версия происхождения частицы бишь: опираясь на мнение ряда историков, М. Фасмер дает ее как аллегровую форму баешь от баю «говорю» (Фасмер 1964, 170). Однако при эллиптических трансформациях слова обычно сохраняется ударный гласный, каковым в данном случае является [а], поэтому более убедительной нам представляется интерпретация Е.А. Галинской, которая доказывает, что бишь - это остаток одной из форм имперфекта (Галинская 2006). Но в наших материалах частица бишь не встретилась; ее мы не рассматриваем. 
языком, возможности эволюции семантики глагольного слова на пути изменения его грамматических функций. Тем самым, те же слова в диалектной речи оказываются более многофункциональными, чем в литературном языке.

Для изучения категории модальности и, в частности, функций модальных частиц иногда бывает необходимо обращение к внеязыковой ситуации, относительно которой порождается высказывание, и/или к предтексту, которым мы, к сожалению, не всегда располагаем. В ряде случаев это мешает однозначности принимаемых нами решений. Однако в связи с целями исследования для нас в первую очередь важно было не точное определение значения модального слова в конкретном высказывании (однозначный «перевод» каждой диалектной цитаты и каждого слова на литературный язык), а установление диапазона семантического варьирования диалектного слова на основании суммы контекстов, принадлежащих частной диалектной системе.

\section{[2] Бы}

Морфологический статус этой частицы как элемента формы сослагательного наклонения в сочетании с л-формой глагола является общерусским и свойствен, в том числе, и севернорусским говорам, например: Всё время бы пели скорее бы не забыли (Пин. Лав.). Наряду с этим в говорах наблюдается незнакомое литературному языку употребление бы в контекстах с формами настоящего, будущего времени и императива

(1) Там бы Го́ра называецце на угоре (Пин. Лав.);

(2) Ну Олёшка тожо бы любит цветы, да ему некогда (Усть. АП);

(3) Сын будет бы сватать девку - посмотрят, што умет делать (Пин. Нюх.);

(4) Она бы споёт (Пин. Нюх.);

(5) Рвите бы лук-от, я не жалею (В-Т. Тин.).

Это свидетельствует о том, что синтаксические ирреальные наклонения в диалекте могут взаимодействовать с категорией времени. Системный статус диалектного бы в связи с этим позволяет считать, что сослагательное наклонение как категория морфологии глагола располагает парадигмой во времени или, иначе говоря, бы является ирреальным модификатором синтаксического плана, функционирующим на уровне сложного предложения и взаимодействующим с временем предиката.

[3] В Национальном корпусе русского языка (НКРЯ), по данным обобщающей статьи Н.Р. Добрушиной (Добрушина 2009), отсутствуют примеры употребления бы с формами настоящего времен, а в конструкции «быl+императив» встречается только глагол быть: «Будь бы товарищ мой не глухой, я протрубил бы ему, мы бы сговорились и ждали бы зайца на той и другой стороне» (М.М. Пришвин. Дружба (1941)). 
В диалектных текстах бы всегда является энклитикой и обычно находится в контактной позиции по отношению к сказуемому, справа или слева от него (мука бы есть и есть бы старушки), но может быть отделено определяющим его наречием: мама бы хорошо работает.

[2.1] Бы в высказываниях с двумя предикатами.

Типичный и преобладающий во всех говорах контекст употребления бы двупредикатная конструкция со строгим расположением частей и сопоставительным или противительным их отношением. $5 b l$, структурно примыкающее к первому предикату, играет роль компонента двухместного союза; вторая кла-

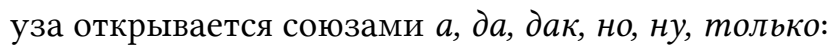

(1) Она зовет бы, да я не хочу (В-Т. Тин.);

(2) У ней больша бы комната, ну холодно, зимой нельзя жить (Пин. Лав.);

(3) Ничего не испекла: мука бы есть, дак дрожжей нету (Усть. АП);

(4) Клуб-от бы дивен ${ }^{4}$ у нас, да сцена маленька (Леш. Кеба);

(5) В красном доме есть бы старушка, только болеет, ей уж под восемьдесят (Пин. Нюх.);

(6) Она бы на все болезни, но ней трудно искать (В-Т. Вдг.);

(7) Есть женщина бы и хорошо шьет, да робенок у ней (Пин. Нюх.);

(8) Она можот бы петь, да не запевает ('не может быть запевалой') (Леш. Кеба);

(9) Теперь бы сытые, а хуже веселяцце (Пин. Нюх.);

(10) И сена хватит бы на корову, только коров нету (В-Т. Тим.).

Содержанием первой части высказывания с бы является реальная позитивная посылка; во второй, начинающейся с $a$, дa, дак, ну, только, сообщается тоже реальный факт, который препятствует предполагаемому позитивному развитию ситуации, логически следующему из посылки в части первой. Тем самым потенциальное (невербализованное) следствие первой посылки противопоставляется содержанию заключительной части. В некоторых случаях в составе высказывания может быть восстановлена еще одна предикативная единица - нереализованное позитивное следствие посылки, сформулированной в первой части. Можно предположить, что бы в этих примерах прочитывается не на фоне предиката первой части с реальной модальностью, а в составе предиката отсутствующей части с ирреальной модальностью: 'клуб большой, поэтому в нем могли бы быть концерты, но...; 'есть старушка, которая могла бы

[4] Дивный - большой, хороший. 
что-то рассказать, но...; ‘женщина могла бы сшить что-то, но...' и т.п. Семантика «нереальности» относится, таким образом, не к вещественному содержанию вербализованного предиката (клуб действительно велик, старушка на самом деле живет в красном доме и т.д.), а к той ситуации (невербализованной), которая не может реализоваться в силу причин, о которых сообщается в конечной части высказывания. Тем самым бы позволяет выявить невербализованный предикат с ирреальной модальностью.

Примечательно, что во второй части высказывания либо имеется отрицание, либо предикат содержит «негативную» сему: маленька, трудно, болеет, холодно ${ }^{5}$.

В присущей этим контекстам ситуации сопоставления рема (реже тема) первой части с примыкающим бы как правило выделяется повышением тона на ударном гласном акцентируемого слова; во второй части понижением обычно маркируется рема, если она относится к тому же подлежащему, либо тема, если во второй части предложение с другим подлежащим (Кодзасов 1996, 194): она

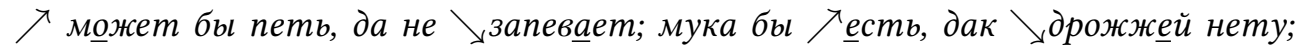

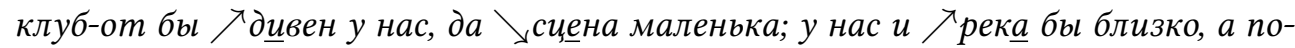
вадились в уколодеи.

Общий прагматический смысл диалектных высказываний такого типа вербально не выраженное сожаление о нереализуемости имеющейся предпосылки: 'поставить концерт с большим количеством участников', 'побеседовать со старушкой', 'сшить одежду' и т.п.

Эта конструкция употребляется в диалектной речи так часто, что становится своего рода формулой, клишированным способом выражения эмоции сожаления о нереализованной возможности осуществления имеющейся предпосылки, а клишированность, как известно, в высокой степени свойственна спонтанной речи вообще и диалектной в особенности (Николаева \& Седакова 1995).

[2.2] Бы в высказываниях с одним предикатом

(1) Она бы женщина трудолюбивая, роботящая (В-Т. Вдг.);

(2) Хорошо бы жить-то, всего бы много (В-Т. Вдг.);

(3) У нас земля бы очень хорошая (В-Т. Вдг.);

(4) Он бы и не старый, семнадцатого году (Пин. Нюх.);

(5) Мне бы не ндравицце так-то жить-ту (Леш. Кеба);

(6) У меня бы щзас хлеб-от есь хорошой бы (Пин. Лав.);

(7) Черёмухи сухой килограмм бы шестнадцать есть (В-Т. Вдг.).

[5] О «позитивной» и «негативной» семантике в антонимических парах качественных прилагательных см. (Апресян 1974). 
Некоторые из приведенных высказываний оставляют впечатление недосказанности, не вербализованной идеи несоответствия существующей ситуации тому, что автору представляется нормальным развитием сюжета, заявленного в первой части ('женщина трудолюбивая, а живет бедно'); однако завершающая интонация, наблюдаемая в ряде контекстов, указывает на их автономный характер и свидетельствует в пользу необязательности антитезы типа 'земля хорошая, а урожаи плохие', 'жить хорошо, а уезжают’ и т.п. Допустимо и позитивное развитие сюжета сообщения: 'земля хорошая, и вследствие этого урожаи большие', 'она женщина трудолюбивая, и поэтому живет хорошо', ‘жить хорошо, и поэтому никто не уезжает'. В режиме спонтанной речи, в диалоге, когда собеседник обладает не только фоновыми знаниями, но ему понятны и эмоции говорящего, которые он сам скорее всего разделяет, антитеза, присутствующая в сознании говорящего, не нуждается в вербализации.

В таких случаях вероятна синонимия частиц бы и ведь в значении, которое предполагает разные пресуппозиции говорящего и адресата: она ведь женщина трудолюбивая; земля ведь очень хорошая, т.е. «удостоверительное» значение частицы, подтверждение того знания говорящего, которое, возможно, не очевидно для адресата (Бонно \& Кодзасов 1998). Иногда такая интерпретация представляется достаточно убедительной:

(8) Выпью редко, не хочу бы пить-то (Пин. Лав.);

(9) Осенью бы отпуск, осенью и приедут (В-Т. Вдг.);

(10) Река-то бы маленька, покупались бы (В-Т. Вдг.);

(11) Не надо покупать, свои бы есть (Пин. Нюх.);

(12) Где у нас старушки? Нет бы боле (Пин. Нюх.).

Две клаузы в составе этих высказываний не связаны семантикой антитезы; они независимы, и при этом бы является частицей, принадлежащей только одной клаузе и «удостоверяющей» значение предиката (не хочу ведь numb-mo; река ведь маленькая; нет ведь боле старушек).

Частица бы, синонимичная модальной частице вед, , соотносит мнения разных субъектных сфер (разных личностей - субъекта и адресата), в отличие от бы в [2.1], которая участвует в соотнесении фактов в рамках одной субъектной сферы - говорящего.

Встречающиеся иногда предложения со сказуемым в форме прошедшего времени $+б b$, омонимичные сослагательной конструкции (и по всей вероятности, сосуществующие с ней в одной системе), не содержат значения ирреальности:

(13) Они бы не запрещали, но мы не могли (В-Т. Вдг.); 
(14) Мама бы хорошо работала, а отеи деньги пропьет (В-Т. Тин.);

(15) Он уж бы и плыл, и ревел ${ }^{6}$, что спасайте, а никого нету (B-Т. Тин.);

(16) Раньше и сыновья бы дома жили, а ноне уезжают (В-Т. Вдг.);

(17) Оне совсем бы меня не касались, а я приглядывалась (Усть. АП);

(18) Так-то там большая бы деревня была, а сейчас домов десять (Усть. АП).

Семантика этих конструкций та же, что и в примерах с формами настоящего времени: бы является сигналом возможного, но не состоявшегося позитивного развития ситуации, а л-форма указывает на отнесение сюжета рассказа к прошлому. Эти примеры подтверждают предположение о том, что бы можно рассматривать как ирреальный модификатор синтаксического плана, функционирующий на уровне сложного предложения и взаимодействующий с временем предиката.

Возможность совмещения разнообразных функций бы в разных синтаксических конструкциях (общерусских сослагательных и специфически диалектных, о которых шла речь выше в [2.1]) в одном речевом тексте иллюстрируют следующие контексты, записанные в д. Акичкин Починок Устьянского р-на:

(19) Хоть и годов много бы, и ничего бы не действует, всё болит, $\boldsymbol{a}$ умирать страшно. Я-то бы рада умреть-то, да нету смерти $\partial а \kappa ;$

(20) Она понимат бы, в медицине, и роботат бы хорошо, да спилась. Она кабы не пила бы, страсть бы хорошо роботат. Bот к нам медика-то эково и сунули. Она вообще знат бы всё дело, опьтная, ну испортилась вся.

[2.3] Бы с императивом.

(1) Чево хош бы делайте (Вил. Клуб.);

(2) Рвите бы лук-от, я не жалею (В-Т. Тин.).

В этом можно видеть смягчительную функцию бы, которая переводит модальность высказывания из директивной в разрешительную, и в связи с этим интересно вопросительное высказывание, адресованное диалектологам:

(3) Университет - это бы с каким уклоном? (Пин. Нюх.).

[6] Реветь - кричать. 
Частица бы в этом случае явно относится не к объективному (диктальному) содержанию высказывания, а включена в апелляцию к собеседнику и выражает уважительное отношение к нему говорящего. Тем самым частица бы, будучи не связана с реальным содержанием высказывания, отсылает именно к форме императива в модусной рамке (ср.: рвите бы - * скажите бы). Смягчительная модальность естественным образом перетекает в форму вежливости: побуждение $(1) \rightarrow$ разрешение $(2) \rightarrow$ вежливость (3) ${ }^{7}$.

Побуждение к действию (или его запрет) с формой императива 2-го лица + бы может иметь косвенный или «смещенный» характер:

(4) Оне бы удочкой-то \ловите, а травить-то бы не Утравите (Вил. Клуб.).

Адресуясь к собеседнику (референту), говорящий (субъект высказывания) сообщает ему свое мнение относительно тех действий 3-го лица (отсутствующего адресата - субъекта действия), которые представляются ему правильными либо неправильными, желательными либо нежелательными. Соединение двух речевых перспектив (субъект речи $\rightarrow$ адресат речи, субъект речи $\rightarrow$ субъект действия) приводит к рассогласованию по лицу субъекта и предиката: благодаря 3-му лицу субъекта действия (оне) соблюдены интересы адресата, поскольку речь идет об отсутствующем лице; формой 2-го лица предиката (ловите, травите) говорящий помещает себя в ситуацию, когда прямым адресатом его высказывания становится отсутствующее лицо, чьими действиями он недоволен.

Частица бы удерживается в аналитической форме императива с глаголом в форме 3 лица настоящего или будущего времени и частицей $n y c m b /$ nycкай:

(6) Уж будет ак сами выучацце как надо, а пускай роботают бы! Пускай робят бы! (В-Т. Тин.);

(7) Пусть бы поживет неделю-то хоть бы у нас! (Пин. Лав.).

Ср. мнение А.А. Шахматова по поводу семантики предложений с 3-м лицом в повелительном наклонении: «Говорящий, выдвигая название действиясостояния... ставит данному третьему лицу обязанность стать его субъектом», которое сопровождается пометкой на полях: «Точно ли при 3-м единственном возможен императив? Не желательное ли это?» (Шахматов 2001, 483).

Транспозиционное употребление императива, при котором бы усиливает ирреальность потенциальной ситуации, наблюдается в следующих высказываниях:

[7] Ср. в (Добрушина 2009, 298) об участии бы при л-предикатах в литературном языке в формировании семантики «смягчения категоричности»: «Частица бы для выражения желания встречается в корпусе значительно реже, чем мы предполагали, причем чаще всего субъектом глагола является адресат, а конструкция имеет значение мягкого совета, рекомендации». 
(7) Хоть топеря бы поезжай - дак ишо правнуков ро́шу, ним помогаю (В-Т. Вдг.);

(8) Восемь классов кончил - поезжай бы учищце, а он вот ещзе и не кончил (В-Т. Вдг.).

В (8) с предикатами временного следования (кончил школу - поезжай) первое действие (окончание школы) является условием выполнения второго (отъезда на учебу), а третье аннулирует ожидаемый результат. Тем самым вербализованной оказывается та предикативная единица в составе высказывания, которая опущена в цитатах из раздела [2.2], и именно туда, на свое «законное место», перемещается бы, означающее потенциально возможное, но не реализуемое действие. Выделительных акцентов здесь два: во второй и третьей клаузах; размещение их характерно для ситуации контраста: поезжай бы \учuтьлся, $а$ он вот еще $u \searrow$ уе кончил (и не поехал). Возможный восходящий акцент на первой и второй клаузе (восемь классов \кончил - поезжай бы \учйться) объединяет первую и вторую клаузу в высказывание с условно-гипотетической модальностью, которое не обладает просодической завершенностью и нуждается в присоединении третьей клаузы с нисходящим акцентом: $a$ он вот eще $u$ $\searrow$ кеннчил.

Многофункциональность бы ведет к десемантизации, которая проявляется в том, что его многократный повтор в речи часто представляется немотивированным, избыточным с точки зрения семантики текста. Например, в разговоре с диалектологами о возможности собрать деревенский хор в д. Лавела Пинежского р-на, было сказано: Моя сестра, да Петровна бы еще, да Пантелевна бы, вот мы бы все бы Каскоменьски-ти, да вот Авдотья бы Кузьмовна, вот с однойто бы деревни, дак бы хорошо спевались, одной-то бы петь-то бы худо. И далее: Там бы Сараева есть, хорошо поёт. В существовании Сараевой и ее способности петь говорящие не сомневаются; бы при этом, очевидно, символизирует припоминание, присоединение еще одного персонажа к названным ранее.

Семантическую избыточность употребления многофункционального «мелкого слова» как характерную черту диалектного дискурса можно наблюдать также и на примере других частиц; например, -om (-mo, -ma, -my, -me): Робо́myту тежо́лу-ту не мо́жот ро́бить-та, а сиде́ть-та мо́жот, гледе́ть-то, ходи́тьто круго́м-ту (Леш. Кеба); Ньинче-то на большо́й-то доро́ге ру́чей-то у ба́ни-то y Па́вла-то до́ма - не текё сейгод (Пин. Шт.); Дак то бы ево́нно-то бы е́сть письмо́-то наве́рно-то (Усть. АП).

Таким образом, в севернорусских говорах бы, помимо своей грамматической роли в качестве союзного средства и модальной частицы, может быть текстообразующим дискурсивным элементом с широкими функциями реализации свойственной диалектной речи инерционности текста: связи фрагментов 
текста, усиления его выразительности путем повтора фрагментов и т.п. ${ }^{8}$ Наблюдаемая при этом десемантизация («семантическое обесцвечивание» или «опустошение») является, как известно, одним из характерных признаков грамматикализации.

Частица-союз бы вне формы сослагательного наклонения функционирует на весьма обширной территории: максимальная концентрация ее наблюдается в говорах среднего течения Пинеги (Пинежский и Верхнетоемский р-ны), несколько менее - в Устьянском и Вилегодском р-нах, единично - едва ли не везде.

\section{[3] БЫBAET}

Изменение грамматического статуса глагольной формы бывает 9 , которая, утратив формы словоизменения, стала частицей/вводным словом при предикатах с грамматической семантикой кратности, известно как литературному языку, так и диалектам, ср.: Придет, бывает, охотник, захочется ему отдохнуть, он и воткнёт топор в дерево (М. Пришвин); диал. Быват до того докосищце, на пожне ${ }^{10}$ родить стане (Плес. Прш.); Как клюквы много осенью, так и ржи будут, а то быват и клюквинки нет (Холм. ПМ.).

Однако в говорах наблюдается формирование у бывает таких семантических характеристик, которые позволяют приписать ему роль союзного средства, а также включить его в число слов-эгоцентриков с эпистемическим модальным значением и проследить не только семантический и морфологический аспекты грамматикализации этого слова, но и сопровождающую его фонетическую деформацию, напр.: Репа-то насеяна - она бай не выростет (B-T. Вдг.).

Исходная словоформа бывает представлена в говорах вариантами: быва́m, быва́е, быва́й, быва́, бай, бват, бат, ба, которые обычно свободно варьируются в двухсложных и в односложных модификациях (напр., в д. Веегора Пинежского p-на - ба, бат, бват, быьва́, быва́m) в зависимости от свойств их позиции во фразе, сохраняя при этом семантическое тождество.

Полная трехсложная форма [быва́ет] или [быва́е] (последнее - в говорах, которым свойственно отсутствие конечного [-т] в форме 3-го лица глагола) существует обычно как глагол/предикат, который, однако, тоже может быть двухсложным [быва́т] в результате стяжения гласных при выпадении интервокального [j]: ([быва[j]ет>бываат>быват]). Таким образом, в виде быва́е, быва́m могут встретиться в одном говоре как омонимичные 1) глагольная форма со стяжением, 2) частица с грамматической семантикой кратности, 3) частица с эпистемической модальностью и 4) союз.

[8] О текстообразующей роли частиц см. (Евтюхин 1979).

[9] В дальнейшем изложении мы используем исходную форму бывает как прототипическую по отношению к эллиптированным модификациям данной лексемы.

[10] По́жня - сенокосное угодье. 
Устойчивое эллиптическое преобразование исходной формы бывает в двухсложную или односложную частицу, занимающую преимущественно безакцентную позицию во фразе, подтверждает идею о том, что «Интегральная редукция слова - стандартный способ маркировки семантического разрыва с исходной лексемой» (Кодзасов 2009, 328) и служит проявлением «фонетической эрозии», которая сопровождает явление грамматикализации: «Once a lexeme is conventionalized as a grammatical marker, it tends to undergo erosion; that is, the phonological substance is likely to be reduced in some way and to become more dependent on surrounding phonetic material» (Heine 1993, 89).

В отличие от бbl, которое не может занимать инициальную позицию во фразе и является устойчивой клитикой, модификации слова бывает чаще занимают инициальную позицию в клаузе и могут быть акцентированы - как двухсложные, так и односложные.

\section{[3.1] Бывает в высказаниях с двумя предикатами}

В конструкциях с двумя предикатами быьает играет роль союза или компонента двухместного союза с соотносительным дак, так. Значение его в этом случае близко к условному если, но не тождественно ему:

(1) Быват не заможешь ${ }^{11}$, дак с голоду умрёшь (Карг. Оз.);

(2) Быват двери польь ${ }^{12}$, он всё выстудит (В-Т. Грк.);

(3) Соляры ${ }^{13}$ бат мало будет, и погасят (электричество) (Он. Лмц.);

(4) Быват ребята пойдут, дак быват и он пойдет (Карг. Оз.);

(5) Бай вы желаете чай, так берите (Плес. Прш.);

(6) По зиме бат худо кормили, дак не дояцце коровы-ти (В-Т. Тин.).

Высказывание в целом имеет гипотетическую модальность, относящуюся к конкретной ситуации: в протазисе с инициальным, как правило, бывает, высказывается предположение о возможном действии или состоянии (говорящий предполагает, что: 'двери открыты', ‘будет мало солярки' и т.п.), а в аподозисе сообщается вероятное следствие этого: 'дома будет холодно', 'отключат электричество’ и т.п.). Цитата (4) имеет двойную гипотетическую модальность: предположение о том, что 'ребята пойдут' и предположение о том, что в этом случае и 'он (вероятно) тоже пойдет'. В протазисе с предикатом прошедшего времени в (6) предлагается причинное обоснование ситуации, о которой сообщается в аподозисе и которая имеет место сейчас; бат обеспечивает модальный характер предположения, относящегося к прошлому: 'возможно (или вероятно), что зимой коров плохо кормили'. Кажущаяся возможной замена бат

[11] Не замо́чь (незамочь?) - стать слабым, беспомощным.

[12] По́лыци - пустой, открытый.

[13] Соляра - солярка, жидкое топливо. 
на если меняет смысл высказывания, переключая модальность предположения о причине конкретной ситуации в условную модальность общего характера.

Ср. у А.А. Шахматова, который интерпретировал модальное значение высказываний в рамках синтаксического «предположительного (гипотетического) наклонения»: «Говорящий, устанавливая связь субъекта с предикатом, делает это не с полной уверенностью, а с оговоркой; это достигается наречиями: кажется, вероятно... при изъявительном наклонении». Здесь же приводится уточнение, представляющее для нас особый интерес: «Областное быьват» (Шахматов 2001, 486). Ср. также цитату из словаря В. Даля: «Бывает, может статься; быват пойдy, может быть, пойду, арх.» (Даль 1955, I: 148).

Таким образом, на базе старой глагольной формы формируется союз с модальным оттенком предположения (гипотезы), а эволюция глагольных форм и их движение в направлении модальных частиц представляется перетеканием смыслов между категориями времени, вида и модальности.

\section{[3.2] Бывает в высказываниях с одним предикатом.}

Преобладающее во всех говорах значение быьвет в контекстах с одним предикатом служит выражением эпистемической модальности: оценки говорящим возможности осуществления предикативного признака, градуированной по степени вероятности, которая иногда конкретизируется или «усиливается» частицами/наречиями может, наверное, ведь, бы и другими:

(1) Ба и голодом придется сидеть. Ба война будет (Нянд. Врл.);

(2) Садитесь чаю пить, быва не пили сёдни ${ }^{14}$ ? (Пин. Лав.);

(3) Олёха-то не знай где, бывай в загуле опять (Пин. Нюх.);

(4) Он запился што-то; быват испортился там на чужой стороньл (Пин. Нюх.);

(5) Ну, Анка, говорю, они бай заблудилисе (Пин. Лав.);

(6) А где девочка-то? Быват лежит? (В-Т. Вдг.);

(7) Не знаю, быва либо дома не была, либо чё, не помню чё-то у ей свадьбы (Пин. Лав.);

(8) Можот дешевле-то быват бы и взял (Он. Лмц.);

(9) Она тожо год-от наверно не помнит быват (В-Т. Тин.);

(10) У нас ба ведь есть тканьё-то? (Нянд. Врл.).

Такое значение способствует формированию союзной функции ба (вероятно, и других модификаций бывает) в альтернативной конструкции:

[14] Сёдни - сегодня 
(11) Там где-то жывё - ба в Ленинграде, ба где (Пин. Врк.).

В приведенных цитатах однозначно прочитывается единичность события, о котором идет речь, и, следовательно, интерпретация через значение многократности, как следовало бы предположить исходя из употребления бывает в литературном языке, невозможна.

Таким образом, семантика «нерегулярности» и «кратности», которая присутствовала в исходной форме глагола бывает, преобразуется в новую оценочную семантику, разрушающую семантику многократности, а следовательно, и связь с категорией вида. Тем самым эллиптированные диалектные слова, производные от глагольной формы бывает, представляют следующую ступень в цепочке грамматикализации, начинающейся с глагола-предиката и кончающейся модальной частицей: он бывает у нее $\rightarrow$ мы, бывает, навещаем ее ('нерегулярно навещаем') $\rightarrow$ диал. он бывает (быват, бат) навещает ее ('может быть, навещает' - неуверенное предположение). Следующей ступенью может быть практически полная десемантизация быьвет, которая иногда компенсируется дублирующими (или усиливающими) частицами либо наречиями может, наверное и другими: (7) - (10).

\section{[3.3] Бывает с императивом}

Таких примеров у нас мало, и роль бывает в них весьма неопределенна: ее можно понять как «поддержку» императивности - (1) - (3) - либо как приглашение к совместному действию - инклюзивный императив (4), где быват может быть понято как проявление вежливости по отношению к референту (ср. подобную функцию частицы бы в [2.3]):

(1) Bы быва noŭme! (Пин. Лав.);

(2) Стас, быват насос включи! (Пин. Нюх.);

(3) Быват не помножку ешьте, а то будешь меня ругать - окоянна эта старуха, окормила меня (Он. Хчл.)

(4) Мало кто делат-то по-старинному, а мне приносят, я камус ${ }^{15}$ шью да деревянны заготовки делаю - быват зайдем в передни комнать-то, да я покажу (Пин. Лав.).

В любом случае, мы здесь имеем дело с высокой степенью десемантизации исходной глагольной формы на пути превращения ее в текстообразующий элемент дискурса.

«Реликты» глагола бывать в виде модальных слов (союзов и частиц) отмечаются на всей территории Архангельской обл., но зоной особенно активного их употребления являются центральные ее районы - Верхнетоемский и Пинежский.

[15] Камус - полоса шкуры с оленьей ноги для подбоя деревянных лыж. 


\section{[4] Буде}

В словарях литературного языка буде дается как союз со значением 'если’ и с пометой «устаревшее» (Ожегов 1972); в грамматике - «Союз буде используется в целях архаизации, а также с иронической окраской. Его употребление ограничено теми случаями, когда обусловливающая ситуация ориентирована в план будущего: Мамашу я приглашу с собой в Ялту в сентябре и потом, буде она пожелает, вернется в ноябре в Москву (Чехов)» (АГ 1980, II: 568).

На территории Архангельской области есть два «разорванных» ареала особенно интенсивного употребления буде: северо-западный (север Онежского и Приморский р-ны), где буде играет роль союзного средства в сравнительном обороте, и южный (Каргопольский, Вельский, Вилегодский, Котласский, Красноборский, Устьянский р-ны), где буде функционирует как союз в условно-гипотетических конструкциях и как модальная частица эпистемического характера. Тем самым, семантические и грамматические характеристики слова буде в этих ареалах существенно различны, и это ставит перед нами ряд вопросов: 1) имеем ли мы дело с омонимичными союзами или с диффузностью семантики (многозначностью) одного слова? 2) следует ли связывать различие в значении буде на разных территориях с различием их происхождения или считать их дивергентами одной глагольной формы? Исходной формой для буде мог бы

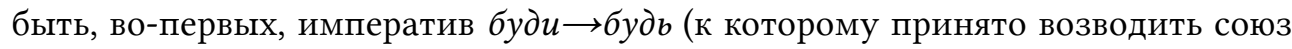
будто), во-вторых - форма 3-го лица индикатива будет. Второе предположение кажется нам предпочтительным хотя бы потому, что сохранение тембра безударного [е] в конце слова характерно для фонетики говоров с полным оканьем; мена же [и] в исходной форме императива буди на [е] в буде маловероятна.

[4.1] Буде в функции сравнительного союза (северо-западный ареал)

(1) Все ляги ${ }^{16}$ полны водой, буде колодцы стоят (Он. Лмц.);

(2) Она (церковь) там буде чаечка белеет (Он. Лмц.);

(3) Хвост роспушилсе буде куделя ${ }^{17}$ (Он. Лмц.);

(4) Борька на одной ноги скачет буде птичка (Прим. Пшл.);

(5) Лампочки буде звездочки горят (Прим. Пшл.).

Сравнение осуществляется на базе сходства образов: 'лужа выглядит, как колодец', 'церковь можно принять за чайку', 'хвост похож на куделю’.

[16] Ля́га - большая лужа.

[17] Куде́ля (кудель) - вычесанный и перевязанный пучок льна, приготовленный для пряжи. 
[4.2] Буде в конструкции с двумя предикатами

В контекстах с двумя предикатами буде может играть роль условного союза в придаточной части сложноподчиненного предложения:

(1) Я задавлюсе, буде ты не пойдешь за меня замуж (Котл. Збл.);

(2) Глубоко у нас сейгод посажена картошка-то, а буде глубоко, дак там опеть холодно (В-Т. Тим.);

(3) Нуда не беда, буде будет (крупа в магазине), дак сама сползаю (Вил. Пвл.).

Это соответствует употреблению буде в литературном языке, где ему приписывается дополнительная роль «архаизации» и «иронического оттенка» (см. выше), отсутствующая в диалектной речи. В условиях конкретной ситуации условная модальность первой клаузы является по существу гипотетической: говорящий высказывает предположение относительно настоящего (5), или будущего (6), (7) действия/состояния и формулирует его реальное следствие:

(4) Буде хорошая погода, дак погребите́ (Усть. АП);

(5) Буде нет замка, дак зайду в избу, коромысло выну (Карг. Лкшм.);

(6) Буде поедешь, тогда посмотрю (Вель. Сдр.);

(7) Буде и пьяный напьется, дак сожгёт буде всё (В-Т. Тим.).

В (7) первое и второе буде создают двойную гипотетическую модальность высказывания: предположение о том, что 'некто может напиться пьяным' и предположение о том, что в этом случае он 'может всё сжечь' (но может и не сжечь).

Заметим, что в высказываниях с гипотетической модальностью клауза с буде всегда находится в протазисе.

\section{[4.3] Буде в конструкииях с одним предикатом}

Буде регулярно употребляется в проспективных контекстах в составе простого предложения с формами будущего времени. Положение буде по отношению к предикату свободное:

(1) А там приедут и увезут буде (В-Т. Тим.);

(2) Весь чай простудили, буде надо подогреть (Усть. АП);

(3) Уедете - опять одна буду, буде одна старушка кака́ зайдет (Карг. Нкл.);

(4) Воды там нет, надо буде из-под слуды ${ }^{18}$ носить или с водокачки (Усть. АП);

[18] Cли́дa- крутой берег реки. 
(5) Вы булку-то ешьте, мне Дуська опять буде принесет (Усть. $\mathrm{A \Pi )}$;

(6) Ты это ешь, а то я буде маме оставлю (Усть. АП).

Особый интерес представляют редкие примеры, в которых представлена форма будет с неутраченным конечным - $m$ :

(7) Тебе, паря ${ }^{19}$, будет двенациать рублей дадут (Вель. Сдр.);

(8) Зашила (начала шить) парню брюки, да не дошью буэт. Не маленькой, оттяну буэт (Мез. Дрг.);

(9) Скажу Митрию, он тебе намякат ${ }^{20}$ будет (Шенк. ВП);

(10) Мы-то сами по себе дак, у меня топере окорёно ${ }^{21}$, а потом роскряжую ${ }^{22}$ будет осенью-ту, на кряжи опеть вві́вожу-ту (вывезти на кряжи - 'вывезти спиленное дерево из леса в виде кряжей’) (В-Т. Тин.);

(11) Кака́-то когды жонка пошла, а мужик-от только што выскочил, дак она одва ${ }^{23}$ не испужаласе: думат, он быват чего сделат со мной будет (В-Т. Тин.).

Дублирование тождественных морфологических и лексических единиц для подчеркивания, «обновления» их смысла чрезвычайно характерно для диалектной речи и проявляется по-разному: дублируется показатель итеративности с целью подчеркнуть идею кратности действия, заложенной (но, видимо, «стирающейся») в глаголах несовершенного вида типа бить - бивать - бивывать, сказать - сказывать - сказывливать и т.п. (Пожарицкая 1991); дублирование приставок (попосле, поподавать, попоехать, поподоить, попоцедить и т.п.); сюда же можно отнести и повтор корня в тавтологических сочетаниях, используемый и в литературной речи (типа бегом бежит, ревмя ревут), но значительно чаще и разнообразнее - в диалектной, как северной, так и южной: из веков веков больница стояла, сидя сидит, до позда́ поздущего, пихко́м пихаются, бродко́м перебредешь, видо́м ненавидит, прыгма́ прыгать, связма́ связать, сижма́ сидеть и т.п. Повтор корня может иметь отличную от повтора афффикса функцию: если значение афффикса, как грамматичное и менее осознаваемое говорящим, может стираться и потому требует дублирования, то корневая семантика - более конкретна, вещественна и потому осознаваема, поэтому повтор корня дает

[19] Па́ря - обращение.

[20] Намя́кать - набить, побить.

[21] Окори́ть - очистить от сучьев ствол спиленного дерева.

[22] Раскряжева́ть - распилить на части (кряжи) ствол спиленного дерева.

[23] Одва́ - едва. 
усиление интенсивности признака и общей экспрессивности выражения. Но в общем плане - то и другое представляют собой явления одного порядка.

В любом случае слово будет, теряющее согласование с полнознаменательным глаголом в форме будущего времени, но сохраняющее не усеченной форму 3 л. ед.ч. (роскряжую будет, будет выучацце), представляется нам промежуточным звеном, этапом грамматикализации глагольной формы в процессе перехода ее в модальную частицу буде, когда глагол утрачивает формы словоизменения, но его форма еще не эллиптирована и сохраняет присущую исходной глагольной форме семантику времени.

Употребление буде (будет) при предикате будущего времени вне условной конструкции согласуется с предположением М.Н. Шевелевой (Шевелева 2008) относительно возможности его независимого употребления в древнерусском языке в качестве глагольной формы, вводящей ситуацию будущего времени, подобно тому как вводит или подчеркивает ситуацию настоящего времени форма есть (В Окичкине наверно уж косят есь - Усть. АП) и ситуацию прошедшего времени - формы было, бывало (Картошка в прошлом году была вся выгнила - Мез. Мос.)

В контекстах с формами настоящего и прошедшего времени, где полностью утрачена связь с глагольной категорией времени, становится вполне отчетливым значение буде как модальной частицы с эпистемическим значением:

(12) Одна тут есть дак пять буде было... буде всех уж сдала $в$ детдом... ну што толку, нарожала да сдала..ллучше бы уж не рожала буде... на оборт ходила, чем государству воспитывать (Усть. АП);

(13) Вот там одна женщина купила дом и вторье... там две семьи... вот третей буде дом купил (Усть. АП.);

(14) Не знаю, чья родня, а буде уж Елене да Петеньке (Усть. АП);

(15) Некоторы дома наверно так буде стояли (Пин. Вгр.);

(16) Буде там есть на лесопункте обша баня (В-Т. Врш.);

(17) Котята там иурчат, буде ходя (Плес. Прш.);

(18) Слишком богомольных у нас буде нету (Красн. ВУ);

(19) (Есть у вас слово 'рада'?) - Радуга буде? (Красн. ВУ).

Буде сообщает высказыванию семантику приблизительности в оценке количества - (7), (12), (13), неуверенного предположения относительно ситуации настоящего или прошлого - (14)-(19).

Эпистемическая модальность естественно перетекает в союзную функцию буде в альтернативной конструкции (ср. аналогичную ситуацию с бывает (ба) в [3.2]): 
(20) Тебя не поймешь ты буде хулишь ${ }^{24}$, ты буде хвалишь (Красн. ВУ);

(21) Буде дак уйдет в лес, буде молотит, буде ткёт (Усть. Снк.).

\section{[4.4] Буде при императиве}

Буде существенно чаще встречается при императиве, чем бы и бblвaеm:

(1) Пойте какую-небудь песню буде! (В-Т. Тим.);

(2) Пойду я капусту поливать, а вы буде чайник выключите (Усть. $\mathrm{A \Pi )}$;

(3) Ты это подтегай буде! (В-Т. Тим.);

(4) Допей буде-ка! (В-Т. Тим.);

(5) Поди буде ты в президенты!! (Усть. АП);

(6) Ты не ходи буде некуды, обрежайсе ${ }^{25}$ (Вель. Пкш.);

(7) Бежи буде к девочкам (Вил. Слн.);

(8) Иди буде ко мне на колени, циган (Вил. Пвл.);

(9) Ну-ко давай буде чаю стокан выпью. Давай, баба, буде мне налей, не жирно только (о чае) (Усть. Снк.);

(10) Давай пойдемте буде набирать (Вель. Сдр.).

Оттенки императивных значений (степень категоричности), сообщаемых разными частицами (ср. 'давай пой', 'пой уж', 'пой, пожалуй', 'пой же' и т.д.), которые в свою очередь многозначны, весьма разнообразны и не могут быть определены вне широкого контекста, включая просодический. Роль буде в наших контекстах можно интерпретировать и как смягчающую директивный характер высказывания, и как дублирующую, усиливающую его подобно частице давай (Левонтина 2005).

Возможны и другие варианты семантики буде: как видим, в (9) буде в сочетании с давай сопровождает и формальный императив (давай буде налей), и формальный индикатив, который принято включать в парадигму императива в качестве формы 1 лица ед. числа (давай буде выпью) (Бирюлин \& Храковский 1992). В этом случае буде представляется синонимичным частице пожалуй в одном из ее значений - 'принятие решения' (Разлогова 1998).

Просмотр значительного массива контекстов с буде показывает, что оно употребляется преимущественно с проспективно ориентированными глагольными формами, что вполне естественно в связи с его союзной ролью в условных и гипотетических конструкциях и при императиве. Однако и при индикативе буде чаще совмещается с формой будущего времени глагола (см. [4.3]).

[24] Хули́ть - осуждать, бранить.

[25] Обрежа́ться (обряжаться) - заниматься домашними делами, в том числе, ухаживать за скотом. 
Возвращаясь к компаративной функции буде ([4.1]), нельзя не отметить ее общности с семантикой предположения, гипотезы: сравнение может содержать «ложное предположение», когда говорящий на основании внешнего сходства как бы приписывает референту неверную интерпретацию наблюдаемого: Идет - дак четыре пролехи (прорехи), буде вся прирвана ${ }^{26}$ идет, буде по кустам лезано (Он. Лмц.).

На основании внешнего вида женщины некто, по мнению говорящего, может предположить, во-первых, что ее юбка разорвана, во-вторых, что это следствие того, что женщина лазила по кустам; но говорящему известно, что на самом деле таков модный покрой юбки, который он, очевидно, не одобряет. Общность компаративного значения и гипотетической модальности просматривается в цитатах из словаря В. Даля: «Буде со. Ежели, если, когда, коли (условно); стар., а в народе местами и ныне будет... а будет нужда придет, покоримся $u$ ей. Буди нвг, в знач. Точно, ровно, словно. Глянь, пыль взнялась, буди кто идет» (Даль 1955, I: 135). В последней цитате клауза с буди может прочитываться как сравнение ('пыль поднялась так, как она поднимается, когда кто-нибудь идет') и как предположение ('возможно, что кто-нибудь идет'). Это показывает диффузность семантики буде, в основе которой сохраняется связь с будущим временем.

Частицу/союз буде в ее союзной и модальной (эпистемической) функции принято рассматривать как реликт одной из форм будущего времени, в которой глагол быть употреблялся в качестве вспомогательного: во-первых, это была конструкция с инфинитивом, которая сохранилась в качестве формы сложного будущего (буду ходить); во-вторых, утраченная конструкция с формой причастия на -л (буду ходил), которую одни историки называют преждебудущим временем (Горшкова \& Хабургаев 1997), приписывая ей таксисное значение временного предшествования, другие - «предположительным наклонением», имеющим «...чисто модальное значение, которое может быть приблизительно передано как 'окажется, что [нечто уже произошло]'... Данная модальная форма выступает в предложениях со значением условия и в придаточных относительных» (Зализняк 2004, 177).

По данным исследователей письменных памятников (Шевелева 2008; Пенькова 2010), эволюция глагольной формы будет в условный союз буде наблюдается уже в XII веке и достигает своего апогея в XVI-XVII веках, когда этот союз становится подлинной приметой делового стиля письма. При этом, согласно наблюдениям Я.А. Пеньковой, «Древнерусские памятники XII-XV вв. содержат много свидетельств функционального сближения будеть именно с условным союзом, данных о сближении будеть с сравнительным союзом нет, а с модальной частицей - крайне мало (по-видимому, последние две тенденции прояви-

[26] При́рванньцй - разорванный, рваный. 
лись гораздо позже первой).» (Пенькова 2010, 208). В подтверждение последнего можно привести следующую цитату: «Ивашка Микитинъ, надеяся на него, архимарита, или буде и по ево поученью, тово старца Александра бранилъ.» (Чел.) Суб. Мат. III, 54, 1666. (Словарь XI-XVII, 345).

[5] РАСПРЕДЕЛЕНИЕ ФУНКЦИЙ БЫ, БЫВАЕТ, БУДЕ В ЧАСТНОЙ ДИАЛЕКТНОЙ СИСТЕМЕ

В системе одного говора обычно сосуществуют два из рассмотренных нами слов, но иногда встречаются и все три. Обозначим эти системы как: I (северозападная) - бьвает, буде; II (южная и юговосточная) - бы, буде; III (центральная) - бы, бывает.

СИСТЕМА І (БУдЕ, БЫВАЕт). Разделение функций частиц буде и различных модификаций быьвет в этой системе достаточно просто и однозначно: буде выполняет роль сравнительного союза: Ларь называли, буде гроб (Он. Лмц.); Глаз не видно, буде ножичком чирнуто ${ }^{27}$ (Он. Лмц.); бывает - частица с эпистемической модальностью в диапазоне 'неуверенное предположение' - 'подтверждение знания говорящего': Я думала Валя бат приедет (Он. Лмц.); Дай поку́рить! - Да у меня бат нету! (Он. Лмц.).

СИСТЕмА ІІ (Бы, БУдЕ). Большинство имеющихся контекстов с бы представляет собой двупредикатные конструкции с антитезой первой и второй клаузы $($ б и буде встроены в конструкции с предикатами разного времени: бы - настоящего/прошедшего, буде - как правило, будущего. Если сопоставить те цитаты с бы, которые можно понимать как завершенные высказывания типа Я бы поваляцие тожо люблю на кровате да (Усть. АП) с цитатами типа Tbы это ешь, a то я буде маме оставлю (Усть. АП), то очевидно, что в первых выражается отношение говорящего к содержанию сообщаемого: (поваляцие ведь люблю), а во вторых формулируется некая гипотеза-выбор относительно предполагаемого действия: $\boldsymbol{a}$ то (пожалуй, тебе не дам, а) оставлю маме.

СИСТЕмА III (Бы, БЫвАЕт). Среди контекстов с бы преобладают, как и в сиСTEME II, двупредикатные конструкции с сопоставительным или противительным отношением частей, где бы выполняет союзную функцию, осложненную модальностью. В высказываниях с одним предикатом бы выражает субъективное отношение говорящего к содержанию высказывания - неуверенность в оценке фактов (Черёмухи сухой килограмм бы (приблизительно, кажется) шестнадиать есть - В-Т. Вдг.), либо используется для подтверждения истинности сообщаемого: У нас старого-то бы ('ведь') много было В-Т. Вдг.). Частица бывает с эпистемической модальностью участвует в выражении отношения говорящего к реальности как неуверенного предположения (гипотезы) относи-

[27] Чи́рнуто - черкнуто, прорезано. 
тельно истинности события или факта: $B$ поле ростут, а в лесу-то бывай не ростут еще (В.-Т. Вдг.); А где девочка-то? Бывай лежит? (В-Т. Вдг.)

Только в говоре д. Тинева Верхнетоемского р-на (едва ли не самом аутентичном из обследованных нами), встретились все три реликта глаголов быть, бывать; приведем этот материал полностью:

Бат/быват:

(1) Я давно песен-то не певала, боле бат сорока годов песен не певала, да всяко спела бы;

(2) Стойками-то бат не столь давно косят;

(3) Я не слыхала, бат нету;

(4) Она тожо наверно год-от не помнит быват;

(5) Сёдне $e^{28}$ подморок ${ }^{29}$, дак комара-то быват больше;

(6) По зиме бат худо кормили, дак не дояцие коровь-ти;

(7) Летом-то бат и живет кто, не знаю;

(8) Ты у нас на имушках ${ }^{30}$-то бат не бывала зимой-ту?

(9) Наболтаю бат чего не гоже.

Бbl:

(10) В колхоз пошли дак бы и тожо дородно бы, ак ить по триста грам дают на трудодень дак тожо дак;

(11) Наa $^{31}$ посылать мне бы похоронна, съездили бы в Ленинградето на могилу-ту;

(12) Мама бы хорошо роботала, а отец деньги пропьет;

(13) Мне бы охота сходить попроведать, да некогда;

(14) А за рекой-то боле бы сухо топере, да некого ешо нету;

(15) Он уж бы и плыл и ревел, што спасайте, а некого нету;

(16) Ак они бы есь немножко, да они червивы;

(17) Она зовет бы, да я не хочу;

(18) Он такой был бодрой, хорошой бы мужик-то;

(19) Рвите бы лук-от, я не жалею;

[28] Сёдне - сегодня.

[29] По́дморок - пасмурно, облачно.

[30] Имушки - деревенский праздник.

[31] На́a- надо. 
(20) Уж будет ак сами выучаџие как надо, а пускай роботают бы! Пускай робят бы!

Будет:

(21) Мы-то сами по себе дак, у меня топере окорёно, а потом роскряжую будет осенью-ту, на кряжи опеть вьівожу-ту;

(22) Кака́-то когды жонка пошла, а мужик-от только што выскочил, дак она одва не испужаласе: думат, он быват чего сделат со мной будет;

(23) Уж будет ак сами выучацце как надо, а пускай роботают бы, пускай робят бы!

Как нам представляется, роли бывает, бы и будет в этой системе достаточно четко распределены: бывает (бат, быват) употребляется как модальная частица с эпистемическим значением 'может быть', 'наверное'; бы реализует весь широкий диапазон своих функций: оно «работает» и как общерусский условный союз - (10), (11), и как союз с модальным значением сожаления о нереализуемости предпосылки, сформулированной в первой клаузе двухчастного высказывания - (12)-(17), и как частица в высказывании с одним предикатом, которое можно интерпретировать и как фрагмент двухчастного высказывания с антитезой содержания первой и второй части, и как завершенное высказывание, где бы синонимично частице ведь (18). В (19), (20) частица бы сопровождает императив.

Значение будет, которое вне системы могло быть интерпретировано двояко (как эпистемическое и как дублирующее значение будущего времени см. раздел [4.1].), в системе, где выражение эпистемического значения определенно принадлежит частице бывает, влечет за собой однозначное толкование будет как дублера-усилителя значения будущего времени.

\section{[6] Выводы}

1. Диалектная речь наглядно демонстрирует общее движение старых форм бытийных глаголов - переход их из грамматики глагольных форм (морфологии) на уровень грамматики высказывания (синтаксиса), в область эгоцентрических слов, обозначающих позицию говорящего.

2. Эволюция модальных слов, восходящих к формам глаголов быть, бывать, показывает, что служебные слова, производные от бытийных глаголов, сохраняют «семантическую память» на уровне обобщенных категориальных значений, таких, как «нерегулярность» для бывает, «будущее» для буде. 
3. Функциональная и семантическая многозначность диалектного слова в условиях жизни вне рамок кодифицированной нормы ведет к его десемантизации, которая сопровождается эллиптическими преобразованиями исходной формы, и в конечном счете оставляет за этими словами роль текстообразующих элементов.

СПИСОК НАСЕЛЕННЫХ ПУНКТОВ АРХАНГЕЛЬСКОЙ ОБЛ. (РАЙОН, ДЕРЕВНЯ):

• Вель. - Вельский; Сдр. - Судрома, Пкш. - Пакшеньга;

- В-Т. - Верхнетоемский; Тин. - Тинева, Вдг. - Вадюга, Тим. - Тимошино, Грк. - Горка, Врш. - Вершина;

• Вил. - Вилегодский; Клуб. - Клубоковская, Пвл. - Павловская, Слн. - Селяна;

• Карг. - Каргопольский; Оз. - Озёрко , Лкшм. - Лёкшмозеро, Нкл. - Нокола;

• Котл. - Котласский; Збл. - Заболотье;

- Красн. - Красноборский; ВУ - Верхняя Уфтюга;

• Леш. - Лешуконский; Кеба;

- Мез. - Мезенский; Дрг. - Дорогорское; Мос. - Мосеево;

- Нянд. - Няндомский; Врл. - Верола;

• Он. - Онежский; Лмц. - Лямца, Хчл. - Хачела;

- Пин. - Пинежский; Лав. - Лавела, Нюх. - Нюхча, Врк. - Веркола, Шт. Шотогорка;

• Плес. - Плесецкий; Прш. - Першлахта;

• Прим. - Приморский; Пшл. - Пушлахта;

- Усть. - Устьянский; АП - Акичкин Починок, Снк. - Синики;

• Холм. - Холмогорский; ПМ - Плёсо-Мякурье;

- Шенк. - Шенкурский; ВП - Верхопаденьга. 
СПИСОК ЛИТЕРАТУРЫ

АГ-80 Русская грамматика I, II. М., 1980.

АОС Архангельский областной словарь. Под ред. О.Г.Гецовой. Вып. 1 АБережок. М., 1980; Вып. 2 Береза-Бяще. М., 1982.

Апресян Ю.Д. Лексическая семантика. М., 1974.

Бирюлин Л.А., Храковский В.С. Повелительное наклонение: проблемы теории // Типология императивных конструкций. СПб, 1992.

Бонно К., Кодзасов С.В. Семантическое варьирование дискурсивных слов и его влияние на линеаризацию и интонирование (на примере частиц же и ведь) // Дискурсивные слова русского языка: опыт контекстно-семантического описания. М., 1998. С.382-443.

Галинская Е.А. Об одном остатке древнеславянского имперфекта в русском языке // Вестник Московского университета. Серия 9. Филология 6/ 2006. С.4760.

Горшкова К.В., Хабургаев Г.А. Историческая грамматика русского языка. М., 1997.

Даль В. Толковый словарь живого великорусского языка. Т.1-4. М., 1955.

Добрушина Н.Р. Семантика частиц бы и б // Корпусные исследования по русской грамматике. М., 2009.

Евтюхин В.Б. Аранжировка диалектных текстов с помощью частии // Севернорусские говоры. Вып. 3. Л., 1979.

Зализняк А.А. Древненовгородский диалект. М., 2004.

Кодзасов С.В. Просодический строй русской речи. М., 1996.

Кодзасов С.В. Исследования в области русской просодии. М., 2009.

Левонтина И.Б. Давай-давай // Язык. Личность. Текст. Сборник статей к 70летию Т.М. Николаевой. М., 2005.

Николаева Т.М., Седакова И.А. Ценностная ориентация клише и штампов 8 современной русской речи // Revue des études slaves. LXVI, 3, 1995.

Ожегов С.И. Словарь русского языка. М., 1972. 
Пенькова Я.А. Будеть как источник формирования служебных слов (на материале деловых памятников XII-XV веков) // Вопросы русского языкознания. Вып. XIII. Фонетика и грамматика. Настоящее, прошедшее и будущее. М., 2010.

Пожарицкая С.К. О семантике итеративных глаголов в севернорусских говорах // Современные русские говоры. М., 1991.

Разлогова Е.Э. Пожалуй // Дискурсивные слова русского языка. М., 1998.

СРЯ Словарь русского языка XI-XVII вв. Вып.1 (А-Б) М., 1975.

ССРНГ Словарь современного русского народного говора (д. Деулино Рязанского района Рязанской области). Под ред. И.А. Оссовецкого. М., 1969.

Фасмер М. Этимологический словарь русского языка. Том I. М., 1964.

Шахматов А.А. Синтаксис русского языка. М., 2001.

Шевелева М.Н. О судьбе древнерусских конструкций с независимыми формами глагола быти в русском языке // Вестник Моск. Ун-та. Сер.9. Филология. 2008. № 6.

Heine B. Auxiliaries: cognitive forces and grammaticalisation. Oxford: Oxford U. Press, 1993.

АДРЕС АвторА

Пожарицкая С.К.

Кафедра русского языка

Филологический факультет

Московский государственный университет им. М.В. Ломоносова

Москва

sofkonst@yandex.ru 